\title{
PENERAPAN PAJAK KENDARAAN BERMOTOR TERHADAP KENDARAAN BERNOMOR POLISI LUAR WILAYAH BALI
}

\author{
I Gede Ivan Wahyu Pramana, Ida Ayu Putu Widiati, Luh Putu Suryani \\ Fakultas Hukum Universitas Warmadewa, Denpasar-Bali, Indonesia \\ Wahyupramana06@gmail.com, Widiati_dayu@yahoo.co.id, Putusuryani099@gmail.com
}

\begin{abstract}
Abstrak
Melihat banyaknya kendaraan dengan nomor polisi luar daerah yang beroperasi di Bali, dalam PERDA Provinsi Bali Nomor 4 Tahun 2016 Tentang Penyelenggaraan Lalu Lintas Dan Angkutan Umum dijelaskan Bahwa Kendaraan dari luar wilayah Bali hanya boleh berada di Bali selama 3 bulan berturut-turut jika melebihi waktu tersebut maka harus melakukan Bea Balik Nama. Penelitian ini dirumuskan untuk mengetahui pengenaan pajak kendaraan bermotor di Provinsi Bali, dan untuk mengetahui intensifikasi pengenaan pajak kendaraan bermotor terhadap kendaraan bernomor polisi dari luar wilayah Bali. Penelitian ini menggunakan tipe penelitian Hukum empiris. Hasil penelitian ini menunjukan bahwa pemungutan Pajak Kendaraan Bermotor di Provinsi Bali dapat dilakukan oleh wajib pajak dengan mengikuti tata cara pelaksanaan pemungutan Pajak Kendaraan Bermotor yang terdapat dalam PERDA Provinsi Bali Nomor 1 Tahun 2011 Tentang Pajak Daerah. Terkait kendaraan bernomor polisi luar Wilayah Bali tidak bisa dikenakan pajak karena tidak adanya peraturan yang mengatur tentang kendaraan tersebut hal ini juga yang membuat Pemerintah Provinsi Bali merencanakan beberapa upaya guna untuk kendaraan luar wilayah Bali yang sudah melewati waktu untuk melakukan Balik nama.
\end{abstract}

Kata Kunci: Pajak Kendaraan Bermotor; Pertanggungjawaban; Intensifikasi Pajak

\begin{abstract}
Seeing the number of vehicles with police numbers outside the area operating in Bali, in the Bali Provincial Regulation No. 4 of 2016 concerning the Implementation of Traffic and Public Transportation it is explained that vehicles from outside the Bali area can only be in Bali for 3 consecutive months if they exceed that time. then must do Transfer of Name Duty. This research is formulated to determine the imposition of motor vehicle tax in Bali Province, and to determine the intensification of motor vehicle tax imposition on police numbered vehicles from outside Bali. This research uses empirical law research type. The results of this study indicate that the collection of Motor Vehicle Tax in Bali Province can be carried out by taxpayers by following the procedures for implementing Motor Vehicle Tax collection as contained in the Regional Regulation of the Province of Bali Number 1 of 2011 concerning Regional Taxes. Regarding vehicles with police numbers outside the Bali Region, they cannot be taxed because there are no regulations governing these vehicles. This has also led the Bali Provincial Government to plan several efforts for vehicles outside the Bali region that have passed the time to reverse name.
\end{abstract}

Keywords: Motor Vehicle Tax; Accountability; Tax Intensification

\section{PENDAHULUAN}

Indonesia dikatakan sebagai negara hukum yang artinya segala sesuatu atau perbuatan baik yang dilakukan oleh pemerintah (pelaksana negara) maupun warga negaranya haruslah berdasarkan atas ketentuan hokum yang berlaku, termasuk juga didalamnya mengenai pengelolaan pajak (Sailan, 2011; Usman, 2014), yang pengaturannya tercantum dalam pasal 23 undang undang dasar negara republik Indonesia tahun 1945. Dalam hal ini pajak dan pungutan lainnya memiliki sifak memaksa atau mewajibkan guna membiayai keperluan umum negara, ini sesuai dengan pasal 23A UUD NRI tahun 1945. Pajak merupakan iuran rakyat kepada kas negara yang berdasarkan undang- undang yang bersifat memaksa/ dapat dipaksakan dengan tidak dapatnya jasa kontraprestasi (tidak ada imbalan langsung bagi pembayaran) dan hasilnya digunakan untuk membayar pengeluaran umum negara (Mardiasmono, 2009; Simatupang, 2018). Pajak diatur dalam undang - undang nomor 16 tahun 2009 tentang ketentuan umum dan tata cara perpajakan. Terdapat juga undang - undang yang mengatur 
mengenai pajak daerah yang dimana pada peraturan perundang undangan diatur dalam undangundang nomor 28 tahun 2009 tentang pajak daerah dan retribusi daerah, dijelaskan bahwa pajak daerah merupakan kontribusi wajib untuk daerah yang terutang oleh pribadi maupun badan hukum yang memiliki sifat memaksa dan tidak adanya imbalan secara langsung serta digunakan untuk keperluan daerah.

Mengenai pajak kendaraan bermotor termasuk dalam pajak daerah tertentu misalnya pemerintah provinsi yang dimana pemerintah provinsilah yang mempunyai wewenang terhadap pajak tersebut. Kewenangan pemerintah provinsi mengenai pemungutan pajak kendaraan bermotor hanya meliputi kewenangan pada bidang pemerintahan yang bersifat lintas daerah serta hasil dari pajak tersebut digunakan untuk memenuhi anggaran daerah dan membiayai pengeluaran pemerintah daerah (Ayza, 2017; Nugroho \& Yuniza, 2012). Di provinsi Bali mengenai tarif pajak kendaraan bermotor penerapannya sudah berjalan tertib untuk kendaraan bermotor lokal (plat DK) sesuai dengan yang diatur dalam perda provinsi Bali pasal 8 perda nomor 1 tahun 2004, akan tetapi banyaknya kendaraan bernomor dari luar Bali yang beroperasi di provinsi Bali melebihi waktu yang telah ditentukan. Yang dimana sesuai dengan ketentuan perda provinsi Bali hanya dibolehkan selama kurun waktu 3 bulan. Jika melebihi ketentuan waktu yang ditentukan maka harus melakukan bea Balik nama.

Berdasarkan latar belakang masalah yang telah diuraikan tersebut, maka dirumuskan beberapa permasalahan yang diteliti yakni untuk mengetahui pengenaan pajak kendaraan bermotor di Provinsi Bali, dan untuk mengetahui intensifikasi pengenaan pajak kendaraan bermotor terhadap kendaraan bernomor polisi dari luar wilayah Bali.

\section{METODE PENELITIAN}

Tipe penelitian yang digunakan dalam penelitian ini adalah penelitian hukum empiris yang menjelaskan fenomena hukum mengenai terjadinya kesenjangan antar norma hukum dengan perilaku masyarakat (kesenjangan antara das sollen dan das sein) (Waluyo, 2002). Sedangkan pendekatan yang dilakukan dengan cara penelitian langsung ke lapangan, menggingat permasalahan yang diteliti oleh penulis adalah peran Badan Pendapatan Daerah Provinsi Bali dan Dinas Perhubungan Provinsi Bali dalam mengurangi banyaknya plat motor luar Bali yang bekerja di Bali. Adapun sumber data yang digunakan dalam penelitian ini yaitu sumber data primer dan sumber data sekunder. Sedangkan Teknik pengumpulan data yang dilakukan adalah pengumpulan data primer dilakukan dengan cara melakukan wawancara dan observasi dengan informan, sedangkan pengumpulan data sekunder dilakukan dengan cara studi kepustakaan dengan cara menelaah peraturan perundang-undangan serta literatur- literatur hukum terkait dengan permasalahan yang diteliti.

\section{HASIL DAN PEMBAHASAN}

\section{Pengenaan Pajak Kendaraan Bermotor di Provinsi Bali}

Pajak kendaraan bermotor adalah salah satu bagian dari PAD (pendapatan asli daerah) yang berasal dari pajak daerah, Berdasarkan pasal 1 undang - undang no 33 tahun 2004 mengenai perimbangan keuangan antara pemerintah pusat dan pemerintah daerah. Pendapatan asli daerah dapat dikatakan sebagai semua penerimaan yang didapatkan oleh daerah dari sumber sumber pada wilayah sendiri yang dipungut Berdasarkan ketentuan peraturan daerah yang sesuai dengan peraturan perundang undangan yang berlaku sumber pendapatan daerah terdiri dari retribusi daerah, pajak daerah, laba dari BUMD (badan usaha milik daerah) serta pendapatan asli daerah yang lainnya yang sudah sah sesuai ketentuan hukum yang berlaku (Wulandari \& Irianie, 2018).

Pajak kendaraan bermotor adalah pajak atas kepemilikan serta penguasaan kendaraan bermotor. Kendaraan bermotor yang dimaksudkan diantaranya semua kendaraan berroda beserta gandengannya yang digunakan di semua jenis jalan darat dan digerakan oleh peralatan teknik berupa motor maupun peralatan lainya yang difungsikan untuk mengubah suatu sumber energi tertentu menjadi tenaga gerak. Pajak kendaraan bermotor termasuk dalam pajak daerah yang dikelola oleh pemerintah provinsi sesuai dengan undang-undang nomor 28 tahun 2009 tentang pajak daerah. Berdasarkan ketentuan peraturan perundang undangan pajak daerah serta retribusi daerah, pengenaan pajak kendaraan bermotor pada dasarnya tidak mutlak ada di seluruh daerah provinsi di Indonesia karena sesuai dengan kewenangan yang diberikan kepada pemerintah provinsi untuk mengenakan maupun tidak suatu jenis pajak di provinsi, maka dari itu sebelum dapat dipungutnya suatu pajak pada daerah provinsi maka terlebih dahulu harus diterbitkannya peraturan daerah mengenai pajak kendaraan 
bermotor guna menjadi landasan hukum operasional dalam pelaksanaan pengenaan serta dilakukannya pemungutan pajak kendaraan bermotor pada daerah provinsi yang bersangkutan.

Mengenai subjek dalam pajak kendaraan bermotor ialah orang pribadi maupun badan hukum yang mempunyai dan menguasai kendaraan bermotor. Dalam hal mempunyai dan menguasai kendaraan bermotor mempunyai makna diantaranya, subjek pajak memiliki kendaraan bermotor, subjek pajak memiliki dan menguasai kendaraan bermotor, ataupun subjek pajak hanya menguasai dan tidak memiliki kendaraan bermotor. Adapun syarat mutlak dalam pengenaan pajak ialah terdapatnya objek pajak yang dimiliki maupun di nikmati oleh wajib pajak, objek pajak kendaraan bermotor dikatakan sebagai kepemilikan maupun penguasaan terhadap kendaraan bermotor dalam peraturan daerah mengenai PKB (pajak kendaraan bermotor). Pengertian kepemilikan maupun penguasaan kendaraan bermotor ditentukan Berdasarkan kepemilikan maupun penguasaan kendaraan bermotor yang terdaftar di daerah provinsi yang bersangkutan serta kepemilikan dan penguasaan kendaraan bermotor di daerah provinsi selama kurun waktu selama 90 hari berturut-turut.

Pelaksanaan pemungutan pajak kendaraan bermotor, adapun beberapa sistem yang digunakan dalam melakukan pemungutan pajak daerah yaitu dengan sistem self assessment sistem pengenaan pajak yang memberi kepercayaan kepada wajib pajak untuk memperhitungkan, menghitung, membayar, serta melaporkan sendiri pajak yang terutang dengan menggunakan surat pemberitahuan pajak daerah. Sistem yang kedua menggunakan official assessmentyaitu sistem pengenaan pajak yang dibayar oleh wajib pajak yang terlebih dahulu ditetapkan oleh kepala daerah maupun pejabat yang ditunjuk melalui surat ketetapan pajak daerah ataupun dokumen lainya yang di persamakan. Dalam pelaksaan pemungutan pajak kendaraan bermotor terdapat tata cara pemungutan pajak yang dilakukan diantaranya, melakukan pendaftaran, penetapan pajak kendaraan bermotor, pembayaran pajak kendaraan bermotor, serta penagihan pajak kendaraan bermotor. Dalam sistem pemungutan pajak dasar dari pengenaan pajak tersebut dimuat dalam undang undang nomor 28 tahun 2009 tentang pajak daerah serta retribusi daerah, dalam pasal 5 dan pasal 6 disebutkan juga mengenai tarif pajak. Tarif pajak dapat dikatakan sebagai ketentuan hukum pajak materil yang sangat penting, dikenakan atas dasar nilai jual kendaraan bermotor serta faktor faktor penyesuaian yang memaparkan biaya ekonomi yang diakibatkan dari pengunaan kendaraan bermotor (Lubis, 2010).

Terdapat dasar dilakukannya pengenaan pajak kendaraan bermotor diperhitungkan dari dua unsur diantaranya nilai jual dari kendaraan bermotor tersebut serta bobot yang memaparkan secara relatif tingkat kerusakan jalan maupun pencemaran lingkungan yang diakibatkan dari pengunaan kendaraan bermotor tersebut. Adanya kenaikan maupun penurunan dari pengenaan pajak terhutang bagi kendaraan bermotor dipertimbangkan melalui asas keadilan dan sebagaimana diartikan untuk kendaraan bermotor yang tarif harganya semakin mahal mengakibatkan pengenaan pajak terutang akan semakin tinggi begitu seBaliknya jika kendaraan bermotor yang relatif harganya semakin atau lebih murah dapat dikatakan pengenaan pajak terhutang kendaraan bermotor tersebut semakin murah atau lebih rendah. Dalam hal dilakukannya pemungutan pajak daerah terdapat pengenaan sanksi terhadap wajib pajak jika terlambat melakukan pembayaran pajak. Sanksi yang dikenakan diantaranya adanya sanksi administrasi yang mencantumkan mengenai pengenaan bunga, denda maupun kenaikan atas ketidakpatuhan dalam menjalankan kewajiban administrasi perpajakan. Terdapat juga sanksi pidana yang menjelaskan wajib pajak serta aparatur pajak mengenai informasi yang tidak benar dalam hal laporan yang menyangkut dengan pemungutan pajak serta penyampaian surat pemberitahuan, akan tetapi melampirkan keterangan keterangan yang tidak sesuai sehingga mengakibatkan kerugian terhadap negara serta kejahatan kejahatan lain yang menyangkut perpajakan yang diatur dalam peraturan perundang undangan yang mengatur mengenai perpajakan.

\section{Intesifikasi Pengenaan Pajak Kendaraaan Bermotor terhadap Kendaraan Bernomor Polisi dari Luar Wilayah Bali}

Mengenai maraknya jumlah kendaraan bermotor yang beroperasi di wilayah Bali dilihat melalui data statistik dari badan pusat statistik provinsi Bali dapat diuraikan dari tahun 2015 hingga tahun 2019 setiap kabupaten/kota yang ada di provinsi Bali mengalami peningkatan secara signifikan terhitung dari tahun 2015 jumlahnya 3.505.984 tahun 2016 jumlahnya sebanyak 3.752 .392 tahun 2017 jumlahnya sebanyak 3.907.094 tahun 2018 jumlahnya sebanyak 4.117.949 dan pada tahun 2019 jumlah kendaraan bermotor yang beroperasi sebanyak 4.352.596. Dilihat dari data yang terhitung oleh badan pusat statistik provinsi Bali dapat disimpulkan adanya peningkatan jumlah kendaraan di provinsi 
Bali yang juga tidak sertamerta diimbaginya dengan Saran Saran ataupun fasilitas perbaikan maupun pelebaran jalan yang dapat menampung jumlah kendaraan tersebut. Hal inilah yang menyebabkan banyaknya kendaraan bermotor yang membayar pajak kendaraannya tidak pada tempat mereka beroperasi.

Berdasarkan hasil jumlah data yang diperoleh dari responden sebanyak 16 orang mengenai permasalahan yang terkait, diperoleh $8,3 \%$ yang pernah terkena/terjaring razia dan sebanyak $91,7 \%$ tidak terkena/terjaring razia terkait dengan kendaraan dengan nomor polisi luar wilayah Bali. Mengenai pertanyaan nomor 2 mengenai keharusan membayar pajak pada tempat mereka berdomisili terdapat sebanyak $37,5 \%$ memjawab tidak dan $62,5 \%$ menjawab iya. Untuk pertanyaan nomor 3 mengenai apakah mereka / responden mengetahui batas waktu seseorang dapat beroperasi dengan kendaraannya di suatu daerah, didapatkan sebanyak $75 \%$ menjawab tidak mengetahui dan sebanyak $25 \%$ menjawab mengetahui tentang hal tersebut. Berdasarkan hasil data yang penulis peroleh dari responden, dalam hal ini dapat disimpulkan bahwa kurannya edukasi mengenai batas waktu dan pengenaan pajak kendaraan bermotor bernomor polisi dari luar wilayah Bali yang beroperasi di provinsi Bali. Untuk responden yang mengetahui adanya peraturan tersebut mereka memilih untuk tetap membayarkan pajaknya pada daerah masing masing dikarenakan menurut mereka lebih mudah dan murah untuk membayar pajak pada daerah mereka berasal dari pada melakukan Balik nama kendaraan bermotor bernomor/plat Bali.

Banyaknya jumlah kendaraan yang berasal dari luar wilayah tidak dapat mempengaruhi pendapatan yang bersumber dari pajak kendaraan bermotor untuk pembangunan daerah. Penerimaan pajak digunakan dalam hal membiayai Saran Saran serta pelayanan terhadap daerah tersebut. sesuai penjelasan undang undang lalu lintas dan angkutan jalan dijelaskan pemilik kendaraan bermotor wajib melaporkan kendaraannya ke pihak terkait apabila kendaraan yang digunakan secara terus menerus dengan kurun waktu lebih dari 3 bulan diluar wilayah kendaraan itu diregistrasi, dan pelaporan terkait kendaraan tersebut dilakukan pada saat pemilik kendaraan sampai di daerah tertentu dalam permasalahan ini khususnya di Bali guna untuk pendapatan serta akan pengawasan terhadap kendaraan tersebut. di provinsi Bali mengenai penerapan peraturan perundang undangan tersebut dalam hal kendaraan dengan bernomor/plat luar yang beroperasi di wilayah Bali sudah berjalan tetapi terdapat beberapa hambatan- hambatan yang diterima oleh badan pendapatan daerah provinsi Bali. Sesuai dengan hasil wawancara yang penulis lakukan dengan I Gusti Ngurah Rai Dharma Wishura,S.Kom,M.T. selaku kepala sub bidang pemeriksaan dan penagihan pajak mengatakan adapun hambatan dalam pelaksanaannya, kurangnya kesadaran wajib pajak dalam hal melapor atau melakukan bea Balik nama dengan alasan agar wajib pajak terhindar dari adanya pajak progresif yang dimana pajak progresif merupakan tarif pemungutan pajak melalui presentase Berdasarkan pada jumlah maupun kuantitas dari objek pajak serta bedsarkanjuga dengan harga maupun nilai objek pajak itu sendiri (Sugianto, 2008). Hal tersebutlah yang membuat badan pendapatan daerah dan dinas perhubungan mengalami hambatan dalam melaksanakan pendataan mengenai jumlah kendaraan yang ada di provinsi Bali. Padahal pemprov Bali sudah memberikan kemudahan dengan dilakukannya pemutihan pajak kendaraan bermotor dalam hal ini dilakukannya pemutihan bukan hanya denda maupun sanksi penunggakan pajak kendaraan bermotor melainkan juga dalam melakukan bea Balik nama pun tidak dikenakan biaya. Untuk pemeriksaan dan juga dilakukannya penagihan pajak daerah terhadap kendaraan bernomor/plat polisi dari luar wilayah Bali tidak bisa dikenakan pajak kendaraan bermotor di tempat dia beroperasi dikarenakan tidak adanya undang undang yang mengatur tentang pengenaan pajak kendaraan bermotor terhadap kendaraan dari luar wilayah Bali. Maka dari itu menangapi dari hal tersebut badan pendapatan daerah dan dinas perhubungan hanya bisa memberikan sosialisasi dan peringatan kepada wajib pajak yang belum melakukan pelaporan dan bea Balik nama yang sudah beroperasi di Bali lebih dari 3 bulan, dilakukannya juga tindakan razia gabungan setiap bulan, dalam tindakan razia gabungan yang dilakukan akan pihak kepolisian. Saran dari dilakukannya razia gabungan adalah kendaraan bernomor/plat luar daerah yang dimiliki oleh orang dengan KTP diluar wilayah Bali yang melebihi batas waktu yang ditentukan (3 bulan) terhitung dari kendaraan tersebut berada di daerah provinsi Bali. Dari hasil kegiatan tersebut terdapat hanya $4,5 \%$ yang melakukan bea Balik nama dan sisanya masih belum melakukan bea Balik nama.

Mengenai upaya dinas perhubungan provinsi Bali terkait dalam penertiban kendaraan bernomor polisi luar wilayah Bali. Dari hasil wawancara yang penulis lakukan dengan Drs. I Gede Gunawan, MSi selaku kepala bidang angkutan jalan, beliau mengatakan sebelum dicabutnya PERDA provinsi 
Bali nomor 8 tahun 2000 mengenai batas usia kendaraan yang hendak masuk ke Bali, hal tersebutlah yang menjadi kendala pajak kendaraan bermotor di Bali berkurang dikarenakan kendaraan yang sudah berumur lebih dari 10 tahun akan tetapi masih menggunakan plat/nomor polisi luar Bali, hal tersebut menyebabkan tidak bisa melakukan bea Balik nama sesuai yang dimaksudkan dalam PERDA. Setelah PERDA tersebut dicabut pada tahun 2018 yang kemudian diganti dengan PERDA provinsi Bali no 4 tahun 2016 tentang penyelenggaraan lalu lintas dan kendaraan umum dijelaskan hanya kendaraan untuk angkutan umum tidak boleh melebihi dari 10 tahun akan tetapi jika kendaraan tersebut digunakan guna keperluan pribadi tidak ada larangan, dengan syarat harus dilakukan nya registrasi teruntuk kendaraan yang berasal dari luar wilayah provinsi Bali yang telah beroperasi selama 3 bulan berturut turut di provinsi Bali. Adapun menangapi hal tersebut, upaya yang dilakukan oleh dinas perhubungan, dinas pendapatan daerah, dan turut serta mengajak SatPol PP untuk mendatangi serta memberikan sosialisasi kepada orang pribadi maupun perusahaan agar wajib melakukan registrasi kendaraan yang mereka gunakan apabila sudah 3 bulan berturut turut berada di wilayah Bali sesuai dengan pengaturannya menurut PERDA provinsi Bali nomor 4 tahun 2016 tentang penyelenggaraan lalu lintas dan angkutan umum. Mengenai hal tersebut juga menimbulkan suatu kendala dalam hal penetapan waktu kendaraan tersebut, karena kendaraan tersebut masa waktu berada di luar daerah dimana kendaraan tersebut sudah berada dan beroperasi di Bali selama 2 bulan, kendaraan tersebut kemBali ke tempat asal selama kurun waktu kurang dari 1 minggu dan kemBali lagi ke Bali. Hal tersebutlah yang membuat masa penetapan waktu pengoprasian kendaraan diluar daerah menjadi mengulang lagi dari awal. Menyikapi hal tersebut dinas perhubungan, badan pendapatan daerah beserta juga dari jasa raharja berencana melakukan pemasangan stiker pada kendaraan yang dari luar yang akan masuk ke wilayah Bali. Dalam stiker yang dipasangkan pada kendaraan tersebut tertera tanggal, bulan, dan tahun kendaraan tersebut masuk ke wilayah Bali. Dilakukannya pemasangan stiker tersebut bertujuan untuk mempermudah dinas terkait dalam melakukan kegiatan/tindakan razia dan memberikan himbauan apabila kendaraan tersebut sudah melewati batas waktu yang sudah ditentukan sesuai dengan pegaturannya dalam PERDA provinsi Bali nomor 4 tahun 2016 dan juga untuk mengetahui apabila masa waktu kendaraan tersebut kemBali ke daerah asalnya dan kemBali lagi beroperasi di wilayah Bali. Tetapi upaya ini masih dalam tahap perencanaan karena masih banyak yang perlu di persiapkan mulai dari persiapan pegawai dilapangan begitupun dengan sanksi jika terdapat pelanggaran terhadap upaya ini. Selain dilakukan pemasangan stiker juga dilakukan pemasangan cctv yang nanti fungsinya untuk mencatat nomor/plat polisi kendaraan yang dari luar Bali agar terdata jumlah kendaraan yang masuk ke wilayah Bali (baik kapan kendaraan itu masuk maupun kapan kendaraan tersebut keluar dari wilayah Bali.

\section{SIMPULAN DAN SARAN}

\section{Simpulan}

Berdasarkan uraian diatas, dapat disimpulkan bahwa pajak kendaraan bermotor dikenakan terhadap kendaraan yang dimiliki atau dikuasai oleh wajib pajak baik itu orang pribadi maupun badan hukum yang terdaftar di daerah dan dioperasikan di semua jenis jalan darat, mekanisme pemungutan Pajak Kendaraan Bermotor di Provinsi Bali dapat dilakukan oleh wajib pajak dengan mengikuti tata cara pelaksanaan pemungutan pajak kendaraan bermotor yang terdapat dalam PERDA provinsi Bali nomor 1 tahun 2011 tentang pajak daerah. Kemudian, pengenaan pajak kendaraan bermotor terhadap kendaraan bernomor polisi luar wilayah Bali tidak bisa dikenakan karena tidak adanya payung Hukum yang mengatur tentang kendaraan-kendaraan tersebut hanya ada peraturan yang mengatur mengenai batas waktu kendaraan tersebut berada di luar wilayah Bali, hal tersebut yang membuat Pemerintah provinsi Bali melakukan dan merencanakan beberapa upaya untuk mengurangi atau menertibkan kendaraan bernomor Polisi luar wilayah Bali, hambatan yang diterima oleh pemerintah provinsi Bali dalam melakukan upaya tersebut yaitu kurang nya data mengenai jumlah kendaraan luar wilayah Bali yang masuk ke wilayah Bali.

\section{Saran}

Berdasarkan hasil penelitian di atas, hendak disampaikan beberapa saran kepada pemerintah provinsi Bali yakni Pemerintah Provinsi Bali perlu membuat regulasi yang jelas terkait mengenai pengenaan pajak dan perpindahan plat nomor luar ke plat Bali serta lebih memperbaiki sistem masuknya kendaraan dari luar daerah sehingga memudahkan pendataan kendaraan keluar masuk ke Bali dan 
untuk lebih memperjelas dan mempermudah tata cara pindah plat nomor sehingga masyarakat tidak kesulitan dalam plat nomor kendaraan. Kemudian, kepada masyarakat yang memiliki kendaraan bernomor polisi luar daerah Bali untuk melakukan Balik nama kendaraan apabila berdomisili atau bekerja di Bali demi terciptanya taat pajak dan pajak yang masuk sesuai dengan kendaraan yang terdata di Provinsi Bali yang dimana pajak tersebut dipergunakan untuk perawatan atau perbaharuan jalan.

\section{DAFTAR PUSTAKA}

Ayza, B. (2017). Hukum Pajak Indonesia. Kencana.

Lubis, I. (2010). Menggali Potensi Pajak Perusahaan dan Bisnis dengan Pelaksanaan Hukum. Gramedia.

Mardiasmono. (2009). Perpajakan. Andi.

Nugroho, A. D., \& Yuniza, M. E. (2012). Pengaturan Pajak Daerah di Provinsi Daerah Istimewa Yogyakarta Dan Kota Yogyakarta. Mimbar Hukum, 24(1), 130-144.

Sailan, M. (2011). Istilah Negara Hukum dalam Sistem Ketatanegaraan Republik Indonesia. $M M H$, $40(2), 228-235$.

Simatupang, T. (2018). Klasifikasi Tindak Pidana Dibidang Perpajakan di dalam Sistem Peraturan Perundang-Undangan di Indonesia. JUrnal Ilmu Hukum Prima Indonesia (IHP), 1(1), 72-92.

Sugianto. (2008). Pajak dan Retribusi Daerah (Pengelolaan Pemerintah Daerah dalam Aspek Keuangan, Pajak dan Retribusi Daerah). Gramedia.

Usman, A. H. (2014). Kesadaran Hukum Masyarakat dan Pemerintah Sebagai Faktor Tegaknya Negara Hukum di Indonesia. Jurnal Wawasan Hukum, 30(1), 26-53.

Waluyo, B. (2002). Penelitian Hukum dalam Praktek. Sinar Gratika.

Wulandari, P. A., \& Irianie, E. (2018). Pajak Daerah dalam Pendapatan Asli Daerah. Budi Utama. 